\title{
Penerapan Metode Smart Games untuk Meningkatkan Hasil Belajar Bilangan Berpangkat Pada Siswa Kelas IX SMPN 1 Kalidawir
}

\author{
Widaryantii ${ }^{1}$ \\ ${ }^{1}$ SMPN 1 Kalidawir, Tulungagung \\ Email: ${ }^{1}$ widaryanti@gmail.com
}

\begin{tabular}{l} 
Tersedia Online di \\
\hline http://www.jurnal.unublitar.ac.id/ \\
index.php/briliant \\
\hline \\
\hline Sejarah Artikel \\
\hline Diterima pada 29 Januari 2018 \\
Disetuji pada 30 Januari 2018 \\
Dipublikasikan pada 13 Februari \\
2018 Hal. 37-41
\end{tabular}

\section{Kata Kunci:}

Smart games, hasil belajar, bilangan berpangkat,

\section{DOI:}

http://dx.doi.org/10.28926/briliant .v3i1.133

\begin{abstract}
Abstrak: Penelitian ini menggunakan jenis penelitian tindakan kelas (PTK). Subjek penelitian adalah siswa Kelas IX B. Dalam penelitian ini peneliti sebagai guru (pengajar), guru kelas (mitra peneliti) sebagai observer proses pembelajaran Operasi Bilangan Berpangkat. Hasil penelitian menunjukkan bahwa penerapan Metode Smart Games untuk meningkatkan Hasil belajar siswa pada materi Operasi Bilangan Berpangkat siswa Kelas IX B SMP Negeri 1 Kalidawir Tulungagung mempunyai kriteria keberhasilan baik. Hal ini dibuktikan dengan adanya peningkatan Hasil belajar siswa berdasarkan nilai post test per siklus dengan nilai di atas KKM yaitu persentase pada siklus I 66,7\% dan pada siklus II 87,9\%. Simpulan yang diperoleh dari hasil penelitian ini adalah bahwa penerapan pembelajaran Operasi Bilangan Berpangkat melalui Metode Smart Games dapat meningkatkan Hasil belajar siswa Kelas IX B SMP Negeri 1 Kalidawir Tulungagung dan dapat mempermu-dah siswa dalam menyelesaikan persoalan Operasi Bilangan Berpangkat.
\end{abstract}

Matematika merupakan ilmu universal yang mendasari perkembangan teknologi modern, mempunyai peran penting dalam berbagai disiplin dan memajukan daya piker manusia. Perkembangan pesat di bidang teknologi informasi dan komunikasi dewasa ini dilandasi oleh perkem $\neg$ bangan matematika di bidang teori bilangan, aljabar, analisis, teori Operasi Bilangan Berpangkat dan ma-tematika diskrit. Untuk menguasai dan mencipta teknologi di masa depan diperlukan penguasaan matematika yang kuat sejak dini.

Mata pelajaran Matematika perlu diberikan kepada semua peserta didik mulai dari sekolah dasar untuk membekali peserta didik dengan kemampuan berpikir logis, analitis sistematis, kritis, dan kreatif, serta kemampuan bekerjasama. Kompetensi tersebut diperlukan agar peserta didik dapat memiliki kemampuan memperoleh, mengelola, dan memanfaatkan informasi untuk bertahan hidup pada keadaan yang selalu berubah, tidak pasti, dan kompetitif.

Standar kompetensi dan kompetensi dasar matematika dalam dokumen ini disusun sebagai landasan pembelajaran untuk mengembangkan kemampuan tersebut di atas. Selain itu dimaksudkan pula untuk mengembangkan kemampuan menggunakan matematika dalam pemecahan masalah dan mengkomunikasikan ide atau gagasan dengan menggunakan simbol, tabel, diagram, dan media lain. 
Pendekatan pemecahan merupakan fokus dalam pembelajaran matematika yang mencakup masalan tertutup dengan solusi tunggal, masalah terbuka dengan solusi tidak tung $\neg$ gal, dan masalah dengan berbagai cara penyelesaian. Untuk meningkatkan kemampuan memecahkan masalah perlu dikembangkan keterampilan memahami masalah, membuat model matematika, menyelesaikan masalah, dan menafsirkan solusinya.

Dalam setiap kesempatan, pembelajaran matematika hendaknya dimulai dengan pengenalan masalah yang sesuai dengan situasi (contextual problem). Dengan mengajukan masalah kontekstual, peserta didik secara bertahap dibimbing untuk menguasai konsep matematika. Untuk meningkatkan keefektifan pembelajaran, sekolah diharapkan menggunakan teknologi informasi dan komumkasi seperti komputer, alat peraga, atau media lainnya.

Dalam proses pembelajaran di kelas sering timbul masalah yang pada umumnya dialami oleh siswa. Masalah yang dihadapi siswa bersifat unik berbeda satu sama lain. Misalnya masalah dan kesulitan ataupun rendahnya hasil belajar yang dialami siswa pada mata pelajaran Matematika bisa terjadi karena berbagai faktor diantaranya (1) Keterbatasan kemampuari, keadaan, minat dan motivasi diri siswa itu sendiri. (2) Situasi belajar di sekolah atau kelas dan kurangnya sarana dan prasarana. (3) Materi pelajaran yang relevan dengan kebutuhan siswa dan (4)Metode mengajar yang kurang bisa dipahami siswa bahkan kurangnya alat peraga dan alat bantu mengajar.

Apalagi mata pelajaran Matematika menuntut kemampuan Guru untuk bisa membuat siswa mengerti dan memahami tentang materi yang diajarkan dengan tidak hanya membaca buku dan teori saja melainkan harus disertai alat peraga, contoh, praktek, latihan soal, seperti soal bercerita dan sebagainya, agar siswa memiliki pengetahuan, keterampilan dan bahkan sikap ilmiah yang berujung pada pemerolehan prestasi belajar yang maksimal.

Berdasarkan hasil pengamatan dalam proses belajar mengajar dikelas, keadaan sekolah, dan melalui peninjauan bidang akademik dan non akademik, diperoleh hasil bahwa keadaan SMP Negeri 1 Kalidawir Tulungagung khususnya Kelas IX B tahun ajaran 2015/2016 dalam pelajaran Matematika belum menunjukkan hasil belajar sesuai dengan KKM yang ditetapkan terutama pada pengerjaan Operasi Bilangan Berpangkat. Padahal, ditinjau dari keadaan fisik sekolah, yaitu ruang Kelas IX B sudah baik dan sesuai sebagai tempat berlangsungnya proses belajar mengajar. Pengamatan pada proses pembelajaran oleh peneliti dapat disimpulkan bahwa pelaksanaan proses belajar mengajar lah yang belum membuat siswa aktif belajar, sehingga kemampuan siswa belum tergali dengan maksimal.

Pada ulangan harian Matematika dengan Operasi Bilangan Berpangkat, di dapat rata-rata nilai sebesar 63,6 dari 33 siswa, padahal Kriteria Ketuntasan Minimalnya (KKM) telah ditentukan nilai sebesar 70. Dan hanya 14 siswa yang mendapat nilai di atas 70 . Hal ini berarti, hanya $42,4 \%$ dari siswa yang telah mencapai ketuntasan belajar, dan yang lainnya memiliki prestasi belajar yang rendah.

Setelah melihat hasil analisa di atas dan tukar pendapat dengan teman sejawat, maka untuk memperoleh hasil belajar yang optimal, tidak hanya memerlukan suatu latihan yang terus menerus, tetapi terlebih dahulu siswa harus mengetahui inti dari materi yang dipelajarinya. Berdasarkan konsep yang mereka 
temukan sendiri di dalam proses pembelajaran, tentu siswa akan lebih bersemangat, dan aktif belajar serta berusaha mencari penyelesaian masalah yang diberikan oleh Gurunya dengan menggunakan kemampuan sendiri. Adanya semangat atau motivasi siswa dalam belajar dan konsep yang tertanam dengan baik, diharapkan siswa mampu menyelesaikan setiap tugas yang diberikan dengan prosedur yang benar, sehingga hasil belajar yang diperoleh menjadi lebih baik dari semula serta terjadi peningkatan prestasi belajar siswa.

Oleh karena itu, demi memperbaiki berbagai masalah yang ada, peneliti memerlukan suatu solusi untuk mengatasi hambatan-hambatan yang terjadi. Akhirnya diputuskan dengan menggunakan Metode Smart Games dalam pembelajaran Matematika ini. Metode Smart Games adalah Metode bermain adalah cara atau pendekatan dengan bermain dalam belajar untuk mencapai tujuan yang diharapkan. Permainan bisa dijadikan sebagai salah satu strategi pembelajaran, karena permainan memegang peranan penting bagi perkembangan anak. Pembelajaran berpusat pada siswa, sehingga siswa diharapkan lebih aktif, antusias, dan berani dalam mencari penyelesaian permasalahan yang dihadapinya, serta memungkinkan siswa menemukan sendiri informasi-informasi yang tadi perlukan untuk mencapai tujuan belajarnya, sehingga prestasi belajar siswa pun dapat meningkat.

Menindaklanjuti permasalahan dan solusi yang ditawarkan maka peneliti tertarik utnuk melakukan suatu penelitian guna ningkatkan hasil belajar bilangan berpangkat dengan menerapkan metode smart games. Sehingga tujuan penelitian ini adalah untuk mengetahui (1) bagaimana penerapan metode smart games untuk meningkatkan hasil belajar operasi bilangan berpangkat pada siswa kelas IX B SMP Negeri 1 Kalidawir Tulungagung dan (2) apakah metode smart games dapat meningkatkan hasil belajar operasi bilangan berpangkat pada siswa kelas IX B SMP Negeri 1 Kalidawir Tulungagung

\section{METODE}

Lokasi yang digunakan tempat penelitian adalah ruang Kelas IX B SMP Negeri 1 Kalidawir Tulungagung Tahun Pelajaran 2015/2016. Alasan peneliti melaksanakan penelitian di tempat ter-sebut adalah peneliti merupakan salah satu Guru mata pelajaran tersebut sehingga memudahkan peneliti dalam melaksanakan penelitian serta dapat menghemat waktu dan biaya. Dalam penelitian ini subjek yang digunakan adalah seluruh siswa Kelas IX B SMP Negeri 1 Kalidawir Tulungagung tahun pelajaran 2015/2016 sehanyak 33 siswa yang terdiri dari 15 siswa putra dan 18 siswa putri.

Metode yang digunakan adalah metode penelitian Tindakan Kelas yang dikembangkan oleh Kemmis dan Mc Taggart (1988) yakni perencanaan (planning), tidakan (acting), observasi (observing) dan refleksi (feflecting). Penelitian ini dilakukan dalam 2 siklus, yang dimulai dari refleksi pada sebelum pelaksanaan perbaikan pembelajaran dimulai. Namun jika setelah siklus ke-II masih belum menunjukkan adanya peningkatan hasil belajar dan pemahaman siswa, maka akandilakukan sampai siklus ke-III. Penelitian ini dilakukan dengan dua siklus, dimana masing-masing diklus dikenai perlakuan yang sejenis dengan bobot yang beda. Dibuat dua siklus dimaksudkan untuk memperbarui system pengajaran yang dilaksanakan. 
Instrumen yang dikembangkan oleh Guru sebagai peneliti disesuaikan berdasarkan kebutuhan data penelitian itu sendiri. Guru atau peneliti mengidentifikasi dan mempersiapkan berbagai ragam instrument yang diperlukan dalam penelitian tindakan kelas ini. Guru ataupun peneliti mempersiapkan instrument penelitian dengan tepat, tentunya supaya data yang terkumpul dapat lebih bermakna dan bermanfaat bagi kegiatan penelitian.

Adapun ragam instrument penelitian tindakan kelas yang telah dipersiapkan yaitu, Rencana Pelaksaaan Pembelajaran sebagai in $\neg$ strument rencana pelaksanaan tindakan. Lembar observasi Guru sebagai instrument utama pengumpul data proses dan lembar observasi siswa, wawancara, angket dan catatan lapangan sebagai instrument pendukung pengumpul data proses. Selain itu juga terdapat instrument pengumpul data hasil, yang dapat dikumpulkan dari hasil belajar berdasarkan soal-soal yang diberikan, serta ketrampilan siswa berdasarkan rubrik yang ada.

Analisis data dari sumber-sumber informasi hasil penelitian di dapat dari (1) Data hasil observasi keterlaksanaan pembelajaran melalui Metode Smart Games dan observasi aktivitas siswa dianalisis secara deskriptif untuk memberikan gambaran pelaksanaan pembelajaran dengan menggunakan Metode Smart Games, (2) Hasil wawancara dengan siswa dianalisi secara deskriptif dengan lembar angket untuk mengetahui pendapat Guru dan siswa terhadap pernbelaiaran. (3) hasil tes siswa tiap soal yang diberi skor kemudian diperoleh nilai untuk setiap siswa. Data yang terkumpul dianalis dengan statistik deskriptif.

\section{HASIL}

Berdasarkan hasil pelaksanaan pada siklus I, II dapat dinyatakan bahwa terjadi peningkatan kualitas pembelajaran yang tampak dan perolehan hasil evaluasi dan keaktifan siswa.

Data siklus I hasil observasi menunjukkan, prosentase keberhasilan kelengkapan menyiapkan alat dan bahan percobaan $45 \%$, prosentase keruntutan langkah-langkah yang ditempuh dalam pelaksanaan percobaan $45 \%$, prosentase keaktifan siswa dalam melaksanakan kegiatan percobaan $65 \%$, prosentase keaktifan siswa dalam mengutarakan pendapat saat berdiskusi $45 \%$ dan prosentase hasil penarikan kesimpulan akhir sesuai percobaan $50 \%$.

Data siklus II hasil observasi menunjukan, prosentase keberhasilan metode kelengkapan menyiapkan alat dan bahan percobaan siswa yang disiapkan $35 \%$, prosentase keruntutan langkah-langkah yang ditempuh dalam pelaksanaan percobaan $85 \%$, prosentase keaktifan siswa dalam pelaksanakan kegiatan percobaan $55 \%$, prosentase keaktifan siswa dalam mengutarakan pendapat saat berdiskusi $88 \%$ dan prosentase hasil penarikan kesimpulan akhir sesuai percobaan $88,3 \%$.

\section{PEMBAHASAN}

Ketika peneliti melaksanakan siklus I, peneliti mengalami berbagai kendala antara lain beberapa siswa masih tampak bingung dalam melaksanakan kegiatan pembelajaran. Masih ada kelompok yang bingung dalam mengikuti langkah-langkah yang tertera dalam lembar kegiatan. Masih ada beberapa siswa yang belum aktif dalam pelaksanaan percobaan. Ketika pelaksanaan diskusi, ada beberapa siswa yang tidak aktif menyampaikan pendapatnya. Dalam 
menyimpulkan hasil percobaan, terdapat 2 (dua) kelompok yang malu untuk presentasi, dan hanya terdapat 3 (tiga) siswa yang mengajukan pertanyaan.

Peneliti kemudian melaksanakan siklus II sebagai perbaikan siklus I, sebelum pelaksanaan siklus II ini peneliti mengganti rencana pembelajaran Metode Smart Games baru yaitu dengan mendiskusikan materi penjumlahan, pengurangan, perkalian, pembagian dan perpangkatan pada suatu bilangan berpangkat bilangan bulat dan bentuk akar. Dalam pelaksanaan percobaan, peneliti senantiasa memberi bimbingan untuk siswanya dalam melaksanakan langkah-langkah sesuai lembar kegiatan. Peneliti pun memberi bimbingan siswa saat berdiskusi untuk menarik kesimpulan. Dengan adanya motivasi guru berupa reward, siswa telah terlihat aktif dalam kegiatan pembelajaran dalam melaksanakan percobaan, presentasi di depan kelas dan berdiskusi menarik kesimpulan. Meskipun ada kendala yaitu beberapa siswa masih belum dapat memahami persoalan yang diberikan, namun dengan hasil prestasi belajar yang dicapai dapat disimpulkan bahwa penelitian tindakan kelas dari siklus II ini telah berhasil.

\section{KESIMPULAN}

Berdasarkan hasil penelitian tindakan kelas yang telah dilaksanakan dalam 2 siklus dengan menerapkan Metode Smart Games dalam pembelajaran Matematika pada siswa Kelas IX B SMP Negeri 1 Kalidawir Tulungagung, dapat dibuat kesimpulan sebagai berikut: Penerapan Metode Smart Games dapat meningkatkan prestasi belajar Matematika siswa Kelas IX B SMP Negeri 1 Kalidawir Tulungagung.

\section{SARAN}

Pembelajaran dengan menggunakan Metode Smart Games pada hakikatnya dapat digunakan dan dikembangkan oleh guru yang menghadapi permasalahan yang sejenis, terutama untuk mengatasi masalah peningkatan prestasi hasil belajar siswa, yang pada umumnya dimiliki oleh sebagian besar siswa.

\section{DAFTAR RUJUKAN}

Dimyati \& Mudjiono. 2006. Belajar dan Pembelajaran. Jakarta: Rineka Cipta.

Kemmis, S. dan Mc. Taggart. 1988. The Action Research Planner. Victoria: Deakin University.

Sudjana, Nana. 2009. Penilaian Hasil Proses Belajar Mengajar. Bandung: Remaja Rosdakarya.

Sudjoko, 2001. Membantu Siswa Belajar IPA. Yogyakarta: FMIPA.UNY.

Sujadi. 1989. Membuat Siswa aktif. Bandung: Bandar Maju. 